\title{
Science foundation ponders its post-Maastricht role
}

Strasbourg. The European Science Foundation (ESF), Europe's 'bottom-up' research organization whose members are national research funding agencies, is still seeking a new role, although its annual assembly in Strasbourg last week failed, despite its efforts, to achieve significant progress towards this goal.

A year ago, ESF had provisionally decided that it would seek the role of the voice of European science at Brussels. But that prize has been snatched from its grasp by the creation of the European Science and Technology Assembly (ESTA).

ESF has been further hindered from achieving its goal by the formal creation of Eurohorcs - the European Heads of Research Councils - which plans to monitor and influence the European Commission's research programmes. That blow has been particularly hurtful, as the members of Eurohorcs are among the ESF's own member organizations.

Other organizations are also competing for influence in this field. The Academia Europea, with more than 1,500 elected members is too powerful for ESF to ignore, according to Lord Flowers, ESF's first president when it was founded 20 years ago. And the newly-formed Alliance of European Academies (ALLEA) is also knocking on the door of Brussels.

But Sir Dai Rees, president of ESF, told the foundation it should not lapse into "graceful retirement". He described the task of the ESF as being to help its member organizations collaborate with each other on international projects.
ESF has a good track record in this field. For example, having held its first European research conferences five years ago, the foundation now functions as a subcontractor to the EU's Training and Mobility programme in the organization of conferences. This year, there will have been 38 ; next year's total should amount to 50 .

Networking is another ESF activity that is flourishing, based on the principle of creating a network of European researchers around a chosen topic. Dervilla Donnelly, the vice-president of the foundation and professor of chemistry at University College, Dublin, boasts that the networks often evolve into research projects that qualify for continuing support from the EU.

Some also recruit funds from outside Europe, such as the taxonomy network, which has US members and support. In future, networks will be required to produce a final document to suggest what should happen next.

The more substantial research programmes, whose cost to ESF ranges from FFr100,000 to FFr1.6 million (US\$18,000 to US\$300,000) a year, again involve Europe-wide collaboration and cover a wide spectrum. ESF's committees have now been asked to identify fields in which future research projects can be mounted profitably.

Last week's assembly also amended the ESF's statutes to remove the possibility that countries such as those of Central and Eastern Europe might acquire associate status, and heard the auditors rap the management over the knuckles for making too much use of overnight courier services. John Maddox

\section{EC commissioner leaves his mark}

Strasbourg. Antonio Ruberti, the European Union's research commissioner who will return to Italy as a professor of systems analysis at the University of La Verna at the end of theyear, is doing every-thing he can to leave a clear desk for Mme Edith Cresson, the former French prime minister who is due to succeed him in January.

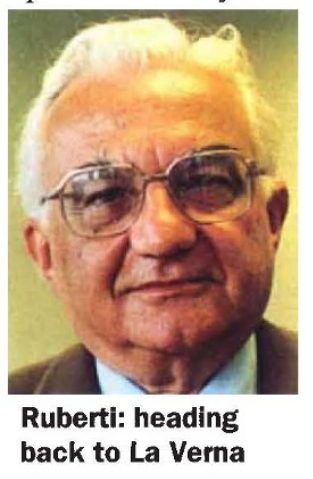

Ruberti is
proud of his two-

year stint as a member of the European Commission. A likeable man, he has persuaded most people to like him. In Strasbourg to address the European Science
Foundation, Ruberti says that the European Science and Technology Assembly (which he set up) is going to be "an independent voice" within the European Union.

But his chief remaining task is to win the approval of the Council of Ministers of a policy to coordinate national research policies within the EU, in order fully to implement the Maastricht Treaty. "Articles $139 \mathrm{H}$, K \& L" repeat all those in Ruberti's circle who know the reference.

Ruberti is confident that he will leave a commission more aware of the importance of research than when he joined, and remains passionate on the importance of links between research and the wider culture. $\mathrm{He}$ pleaded last week for an open system of science and technology that would, among other things, be responsive to the economic needs of Europe.

\section{Transport ban raises new hurdle to nuclear waste store}

Paris. A local court in northern Germany last week blocked the transport of the first consignment of nuclear waste to the controversial interim storage repository at Gorleben from the Phillipsburg power station in BadenWürttemberg. The decision buys time for Germany's anti-nuclear movement, which is using Gorleben as a hostage in its efforts to prevent the continued use of nuclear power in the country.

The interim storage repository has stood empty for 11 years. It forms part of a huge complex at Gorleben that also includes a pilot conditioning plant for compacting waste for burial in the adjacent planned deep storage repository.

The storage of nuclear waste is not itself the main issue; even if Germany closed all its nuclear power stations tomorrow, existing waste - and that from dismantled plants - would still have to go somewhere.

But blocking waste storage is one element in a two-pronged strategy by antinuclear groups to persuade Germany to pull out of nuclear power altogether. The other has been to stall the opening of plants for producing mixed oxide fuel (MOX), on the grounds that industry uses reprocessing to reduce waste, but needs MOX to dispose of the plutonium this produces. MOX plants would therefore also commit Germany to continue using nuclear power.

"We don't want to separate the question of waste from that of the future of nuclear power," says a spokesperson for Greenpeace. So far the strategy has been effective; the political uncertainty it has created has led to a de facto moratorium on the building of new power stations in Germany.

Last week a court in Lüneberg, Lower Saxony, ruled that no waste could be brought to Gorleben pending the outcome of a challenge by local residents to the interim repository's permission to operate. But the company that runs the site, Brennelementlager Gorleben, has appealed to a higher court, which will rule in January.

Uta Kreutzenbeck, a spokeswoman for the ministry of environment of Lower Saxony - which opposes nuclear power - says that the state is also concerned about the safety of the 'Castor' flasks used to transport and hold the waste. It refused a previous attempt to deliver nuclear waste on these grounds in July, but was later overruled by the pro-nuclear federal government.

Kreutzenbeck also argues that the feasibility of safe long-term storage of nuclear waste has not been demonstrated anywhere in the world, and that there is therefore "no sense" in interim storage. "Waste should remain at the power stations," she says.

Declan Butler 